\title{
The hunter-gatherer site BES II (Jacaré-Guaçu River low terraces, central Sao Paulo state, Brazil): Interface with geomorphical and environmental fluctuations of the Pleistocene-Holocene transition
}

\author{
Fabio Grossi dos Santos ${ }^{1,2}$, Pedro Michelutti Cheliz ${ }^{3}$ \\ 1. Museu de Arqueologia e Etnologia, Universidade de São Paulo (MAE-USP), São Paulo, Brazil. \\ Email: fabiogrossi@usp.br \\ 2. Municipal Museum of Jahu, Jahu, São Paulo, Brazil. \\ 3. Centre of Environment and Coastal Studies. NEAL, IG-UNICAMP. Universidade Estadual de Campinas, \\ Campinas, São Paulo, Brazil. Email: pedro.cheliz@ige.unicamp.br
}

\begin{abstract}
:
The lithic site Boa Esperança II (BES II), in the São Paulo segment of the Brazilian Plateau, next to the boundary between the cities of Araraquara (SP) and Boa Esperança do Sul (SP), presents a collection of almost 2,000 lithic artifacts (predominantly chert and sandstone), being interpreted as a settlement of diversified functions with possibly continuous or successive occupation. In this work, we approach the site based on interface of its insertion in the regional physical-environmental context with emphasis on the interface with relief frames, surface structure study and estimated geomorphic sequences of the alluvial plain of Jacaré-Guaçu river - and techno-typological analysis. It was verified that the BES II artifacts are distributed along vertical profiles and relief pictures lined by records that mark the transition from semi-arid conditions to others of increasing humidity, successive oscillations of base levels and modifications of fluvial regimes (ephemeral channels passing to perennial channels of different hydrological meandrings patterns), indicating that human occupation has dealt with conditions of quite distinct landscapes between the Late Pleistocene and the Holocene. Local lithic industry would have taken advantage of attributes derived from these modifications in the landscape over time - in particular the exposure of gravels of large river pebbles deposited by torrential ephemeral channels. The past abundance of raw material of fluvial origin would have contributed to the location of the site in the regional geomorphological context, as well as for a lithic assemblage based on the production of large unipolar flakes. We observed in the correlations between the position of artifacts, geomorphical and pedological data, OSL and Carbone-14 dates at archaeological levels, elements that allow us to discuss considering BES II as an archaeological site to integrate the interval of the Pleistocene-Holocene transition and to had interfaces with the geomorphological and environmental changes of such time. The archaeological implications of the issue and the fact that only one dating of photoluminescence has been reported from the deepest level of the site (basal gravel layer) emphasize the need for new, denser and more diversified studies.
\end{abstract}

Keywords: hunter-gatherers; São Paulo; Pleistocene-Holocene Transition; geomorphology; JacaréGuaçu River

Published by the School of History, Classics and Archaeology, University of Edinburgh ISSN: 2055-0472. URL: http://journals.ed.ac.uk/lithicstudies/ 


\section{Introduction}

Studies and discussions involving the extension of the antiquity of lithic Paleoindian archaeological sites identified until now, show diversified perspectives. The term Paleoindian, for this article in specific, will be referred to as a temporal scope which usually covers the pre-ceramic and pre-agricultural archaeological record in the Americas prior to 8000 years before present (B.P.) (Araujo 2004; Araujo \& Neves 2012).

Paleoindian sites include a record of very diverse materials under a single blanket designation (Lee \& Devore 1968). Ranging from the stone projectile points of the North America, to the petroglyph symbols carved on the walls of the south eastern Andean mountain range, from the human workmanship in fragmented pieces of mammoth bones from the valleys of Alaska, to the human bones of the people of Luzia in the caves of Lagoa Santa, in the heart of the Brazilian plateau.

In the current Brazilian territory, there have been registered Palaeoindian lithic sites (sites at which all or almost all of the artifacts found were made from lithic materials) with such attributes that enable a discussion of its insertion into the temporal context of the Pleistocene-Holocene transition (13,000-8,000 years B.P) (Bueno et al. 2013). The present article tries to characterize one new archaeological lithic site that meets these conditions. It is the site of Boa Esperança II (BES II), on the Brazilian plateau segment near the geographic centre of the state of São Paulo, in the county of Boa Esperança do Sul.

Evidenced initially by preventive archaeology (Zanettini Arqueologia 2003), it was later the object of academic study with regional archaeological approach (Santos 2011; 2013) and with a focus on human occupational interfaces with physical-natural context (Cheliz 2011; 2012; 2013; 2015; 2016; Cheliz \& Oliveira 2011).

Photoluminescence dating connected to the BES II site - if duly accepted - would place the site near to the transition between the Pleistocene and Holocene. However, the inferred antiquity would be considered unusual for the São Paulo segment of the Brazilian Plateau where it is located (see Table 1 and Figure 1), but recently, new studies (Araujo \& Correa 2016; Correa 2017; Troncoso et al. 2016) indicated the presence of other archaeological sites in the region which obtained dates that also suggested association with the PleistoceneHolocene transition, including some with possible ages prior to 10,000 years b.p. (Table 1 and Figure 1), which chronologically stand out amid the previous absolute Paleoindian dates in São Paulo (Mendes 2014; Vilhena 1983). This emphasizes the need to resume research at the BES II site, with care to verify whether its insertion in the chronological context is consistent with the obtained dates.

Table 1. Potential Palaeoindian sites of São Paulo state, with dates prior to 10,000 years before present (except the coast). Map numbers refer to the numbers on the map in Figure 1. Source: adapted from Santos (2011).

\begin{tabular}{|c|c|c|c|c|c|}
\hline $\begin{array}{l}\text { Map } \\
\text { number }\end{array}$ & Site name & Municipality & Methods & Dates & References \\
\hline 1 & Alice Boer & Ipeúna & $\mathrm{C}-14, \mathrm{TL}$ & $\begin{array}{l}7500 \text { BP (C-14) (Araujo) } \\
14200 \pm 1150 \text { BP (C-14) } \\
\text { (Beltrão) } \\
10970 \pm 1020 \text { BP (TL) (Beltrão) }\end{array}$ & $\begin{array}{l}\text { Araujo et al. 2017; } \\
\text { Beltrão } 1974\end{array}$ \\
\hline 2 & $\begin{array}{l}\text { Boa } \\
\text { Esperança } 2\end{array}$ & $\begin{array}{l}\text { Boa Esperança } \\
\text { do Sul }\end{array}$ & OSL, C-14 & $\begin{array}{l}14500 \pm 3000 \mathrm{BP}(\mathrm{OSL}) \\
8850 \text { to } 8835 \mathrm{BP} \text { cal (C-14) }\end{array}$ & $\begin{array}{l}\text { Santos 2011, Cheliz } \\
2016 \text { and this work }\end{array}$ \\
\hline 3 & Bastos & Dourado & C-14 & $12600 \mathrm{BP}$ to $7650 \mathrm{BP}$ & $\begin{array}{l}\text { Araujo \& Correa } \\
\text { 2016; Correa } 2017\end{array}$ \\
\hline 4 & Caetetuba & São Manuel & C-14 & $11080 \mathrm{BP}$ to $9245 \mathrm{BP}$ & Troncoso et al. 2016 \\
\hline 5 & $\begin{array}{l}\text { Lagoa do } \\
\text { Camargo } 1\end{array}$ & Rio Claro & C-14 & 10.800 to $8.300 \mathrm{BP}$ & Araujo et al. 2017 \\
\hline
\end{tabular}




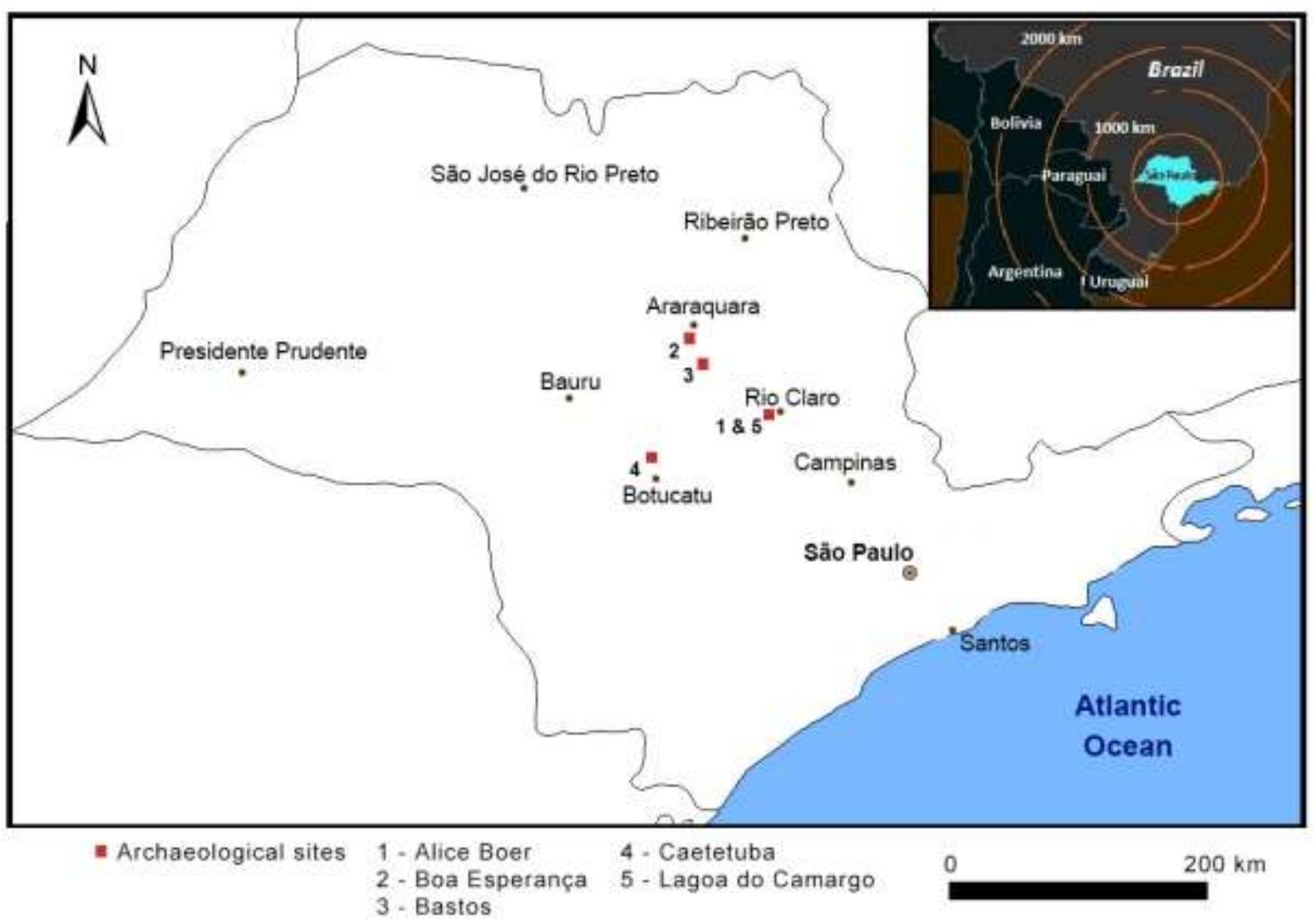

Figure 1. Archaeological sites with absolute dates prior to 10,000 BP in Sao Paulo state, Brazil. Location of the Boa Esperança II site (number 2), in the context of the dated archaeological hunter-gatherer sites in the state of São Paulo (except the coast). 1. Alice Boer; 2. Boa Esperanca II; 3. Bastos; 4. Caetetuba; 5. Lagoa do Camargo. Alice Boer and Lagoa do Camargo are presented on the map as a single point, because the distance between them is smaller than the visual acuity of this map, but are located some kilometres from each other. Sources: Cheliz 2018 - after Santos 2011; Araujo \& Correa 2016; Troncoso et al. 2016; Araujo et al. 2017.

As a contribution to the current discussions, we seek to perform a deepening on interfaces between aspects linked to technologic attributes of its lithic industry and the environmental frames, with focus on geomorphological data. We hope with these procedures to present the summary characteristics of the local lithic industry, weighted by the insertion of the geomorphic context.

The data referring to the geomorphological context involves retrieving and discussing with base on Cheliz $(2011 ; 2012 ; 2013 ; 2015 ; 2016)$ work. Geological, clinographic and altimetric mapping were performed with a combination of works and field measurements and consultation of bibliographic material. The mentioned data were overlaid aiming at the delimitation of relief partitions (Ab'Saber 1969) which corresponded to relatively homogeneous lithic and morphometric (altitudes and ground inclinations) standards. Simultaneously, in the excavation units of the BES II site, sedimentary and pedological profile descriptions were made. Also, a series of auger holes were made in an attempt to three-dimensionally rebuild the variations of the local soils and sedimentary covers - analyses of the superficial structure of the landscape (Ab Saber, 1969). It was then sought to contextualize it within the group of relief partions previously defined.

Regarding the analysis of the archaeological material (Zannetini Arqueologia 2003; Santos 2011), we used as guidelines the concepts of techno-typology, following the methods from Bueno (2007); Morais (1983); Laming-Emperaire (1967); Tixier et al. (1980), and Vilhena (1980). The guidelines cited are examples of widely used systems. This provided standardized language and should facilitate dialogue among researchers. This was the 
approach employed for the "reading" of the encountered lithic industry based on unipolar fragments, which had a low incidence of formal tools.

\section{Location context of the Boa Esperança II site in the regional cuestiforms relief}

The BES II site is located in the south-southeast area of the tropical and subtropical extensions of the Brazilian Plateau, on its meridional segment. More precisely, it is in the area covered by the original extensions of the territory surrounding the city of Araraquara. It is 15 kilometres from the previously mentioned city, and about 250 kilometres from the São Paulo city, the capital of the state of São Paulo. The compound of inner ridges - cuestas, in the designation proposed by Almeida (1964) - in which the BES II site is located, appears with verticals breaks of a few hundred metres associated with basaltic eruptive rocks and clastic sandstone lithology of Mesozoic formations (Figure 2). In certain sectors they are seen superimposed by unconsolidated sediments and Cenozoic alteration horizons.
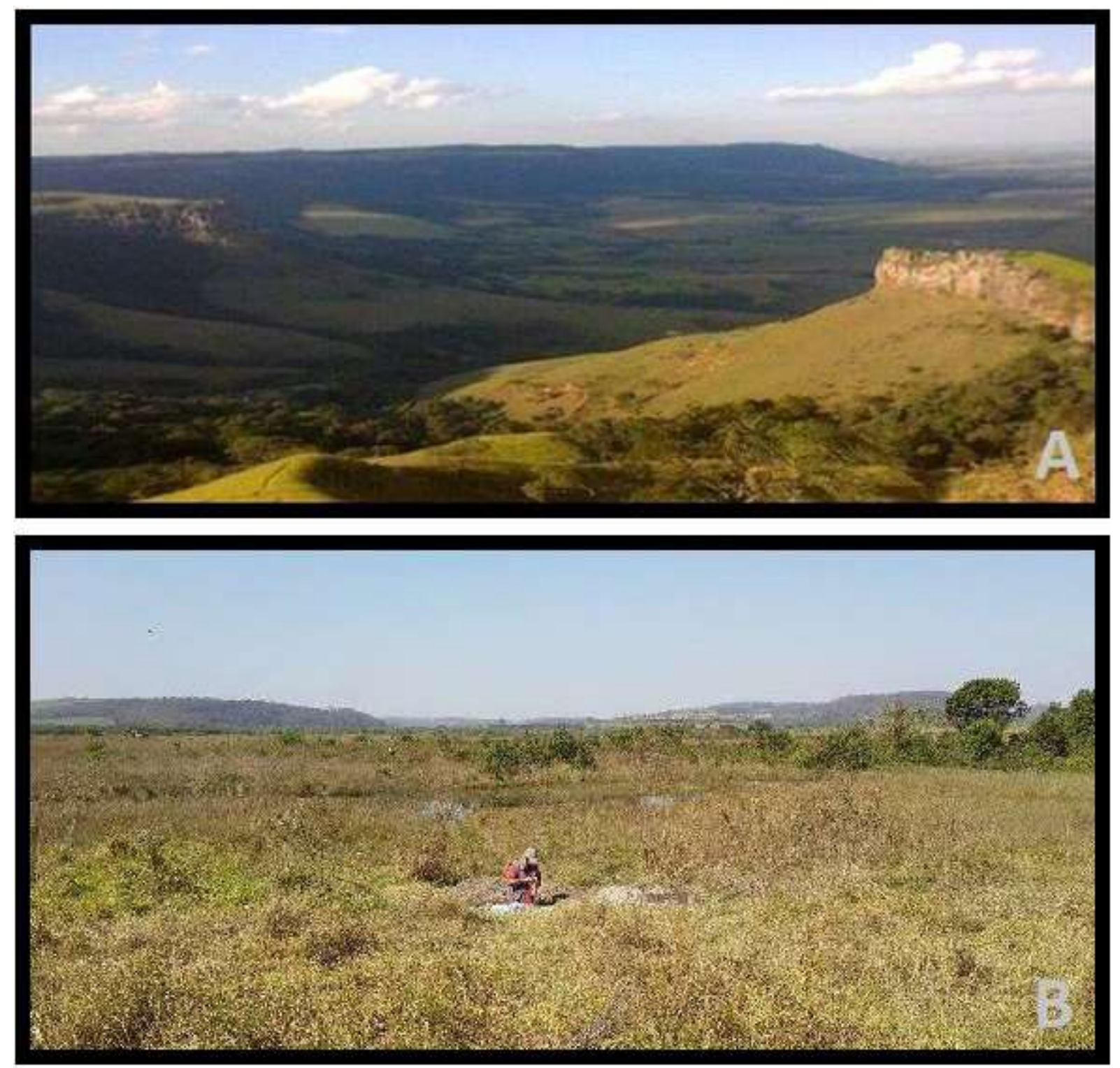

Figure 2. General aspects of the cuestiform segment in the São Paulo State, in the front of external escarpments view from South to North (A) and in the internalized set view from southwest to northeast(B), near BES II site. Source: adapted by Cheliz, photos by Franciely Oliveira (2015) and Fabio Grossi dos Santos (2017). 
The BES II site is located at a far distance from the group of fronts in the external escarpment segments (Almeida 1964). It is an internalized set among the morphological breaks in the cuestas escarpments, situated within a context of relative smoothing of the medium slopes and vertical ranges (Cheliz 2011; 2016).

The characteristics of the morphological attributes of the regional context which form the BES II site can be made in brief from three large relief partitions, defined from a combination of lithological and morphometric - altimetry or slope - attributes (Figures 3 and 4). They are the Araraquara Highlands (marking the more elevated areas, based on smoothed slopes), the Mogi-Guaçu Lowlands and the Jacaré-Guaçu Rivers (lower altimetry areas, also associated with reduced slopes - where the BES II site is found) and the Transitional Levels (the group of slopes and hillsides of more expressive declination responsible for the altimetric and geomorphic transition between the two previous compartments, similar to the fronts).

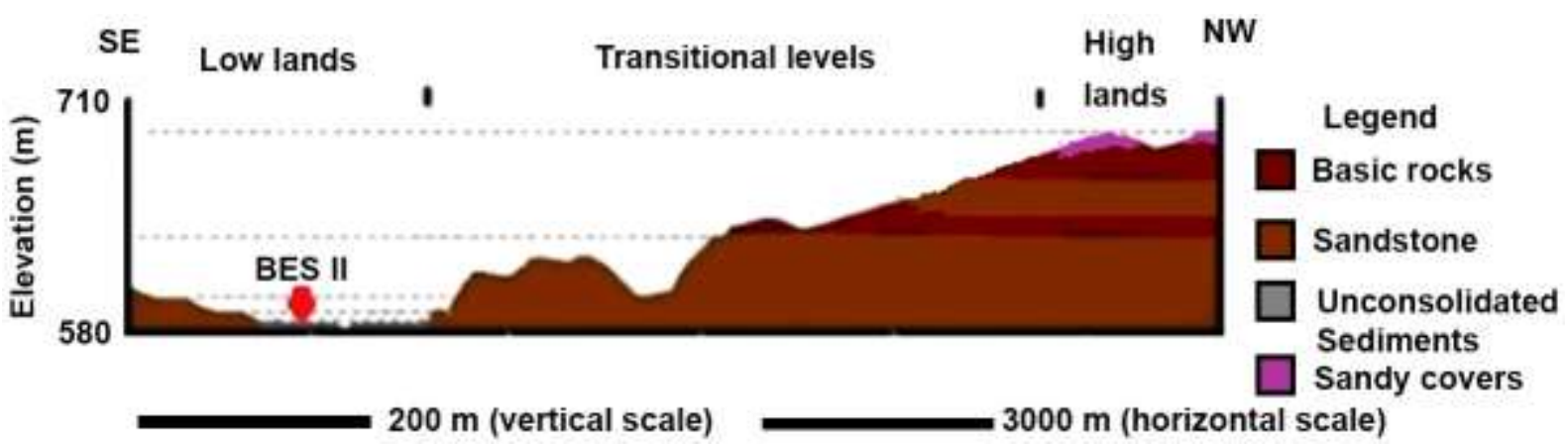

Figure 3. Morphological-geological profile illustrating summary features and layout of the relief picture and main lithological units. Source: adapted from Cheliz (2015).

The positioning of the BES II site within the partitions of the relief on the area can be analysed, among other perspectives, by referring to the potential summary natural attributes for human occupation linked to the way of life of the hunter-gatherers. Among them, one can note the presence of clean water sources, relief features close to flat for the formation of settlements, and sources of raw material for making stone tools. We have found that adequate water sources are common to all relief partitions in the form of perennial rivers and streams. The presence of relief features with significant extensions close to semi-flat surfaces are more common in the Highlands - extensive interfluvial and smoothed slopes - and Lowlands - wide fluvial terraces linked to Jacaré-Guaçu River and its tributaries. Raw material sources in turn are more common in the Transitional Levels. Notably rocky outcrops of sandstones, which are visible more frequently there due to the higher slopes and less thicken soil horizons of the Transitional Levels compartment. The deeper mantle of soils on the Highlands and Lowlands correlate these two compartments with the rare presence of exposed rock.

By overlapping the other known sites and lithic outcrops in the study area, we found that the majority of them are superimposed on the relief compartment of the Transitional Levels (Figure 4). Since potable water sources are common to all compartments, it can be suggested that the more pronounced presence of rocky outcrops - presented as a characteristic of the Transitional Levels - appears to stand out in relation to the availability of semi-flats relief frames presented by the Highlands and Lowlands (Cheliz 2011; 2015; 2016).

When considering its insertion into the regional relief scenario, it should be noted that the location of the BES II lithic site in the Lowlands is an exception in the study area. At the same time, the abundance and diversity of registered BES II artifacts, compete even with some of the richest regional sites present in the Transitional Levels (Cheliz 2012; Cheliz \& Oliveira 2011) 


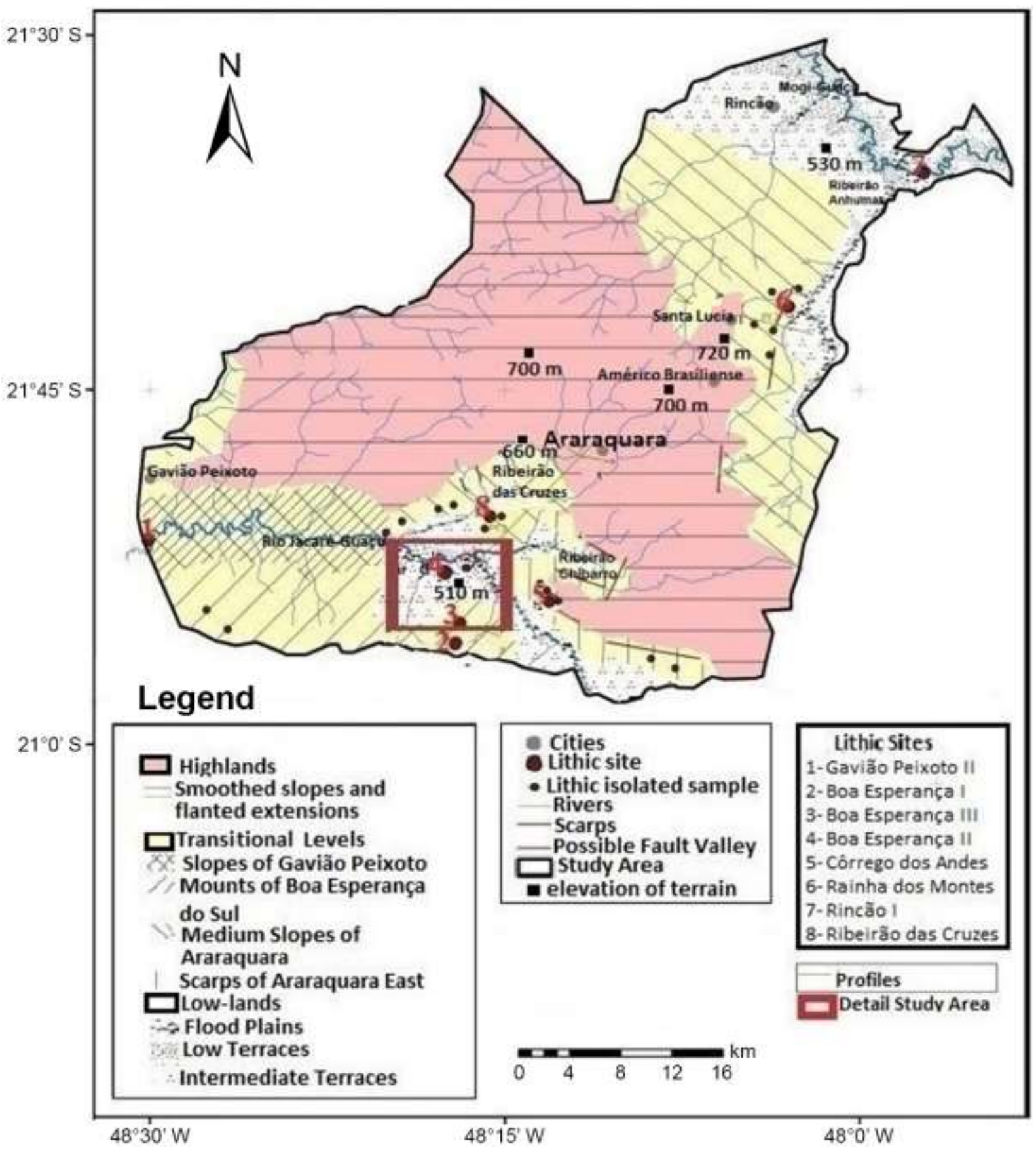

Figure 4. Regional relief partitions and distribution of lithic sites, highlighting lithic sites identified in the region, including BES II. Source: adapted from Cheliz (2016).

The search for the discussion of the possible meanings of this installation in a different morphological context leads to the search for new approaches. It shows how pertinent the need to problematize an analysis and a more accurate description of the interface of archaeological material records of the site with its proximal physical base - the lowlands of the Jacaré-Guaçu River.

\section{Presentation of the lithic industry of the Boa Esperança II site in the context of the semi-detailed relief scenario of the lowlands of the Jacaré-Guaçu River}

According to the semi-detailed geomorphic patterns (Figures 5 and 6), the BES II site is located on low fluvial terraces marked by soils under gleization on the left bank of the Jacaré- 
Guaçu River, a tributary of the Tietê River, predominantly between 485 and $500 \mathrm{~m}$ in the midst of the lowlands of the internal level of the cuestiforms Escarpment. The site is located in a clearly asymmetric segment of the alluvial plain of Jacaré-Guaçu, linked to its own positioning and preservation. On the left bank, the low terraces where the BES II site lies present kilometric floodplains as it approaches the current meandering course of the JacaréGuaçu River, and, on the right bank, the same plains often do not exceed a few tens of metres (Figure 6). Abandoned meanders with different sizes (suggesting variations in hydrological perennial river patterns over time) and orientations are distributed on both the low terraces and floodplains (Cheliz 2013; 2016) (Figures 5 and 6).



Figure 5. Details of abandoned meanders of low lands of the Jacaré-Guaçu River (ancient Araraquara). Details of the surface coverage of the low terraces on which the BES II site is located. Source: adapted from Cheliz (2013; 2016). See Table 2.

Table 2. Essential attributes of abandoned meanders.

\begin{tabular}{lccc}
\hline $\begin{array}{l}\text { Abandoned } \\
\text { meanders }\end{array}$ & $\begin{array}{l}\text { Direction and sense } \\
\text { of symmetric axis }\end{array}$ & $\begin{array}{l}\text { Average width of } \\
\text { palaeochannels }\end{array}$ & $\begin{array}{l}\text { Average length of } \\
\text { symmetric axis }\end{array}$ \\
\hline Type I & N30W/NW & $80 \mathrm{~m}$ & $300 \mathrm{~m}$ \\
\hline Type II & $\begin{array}{l}\text { N2OW/NW, N30W/NW, } \\
\text { W-E/W and W-E/E }\end{array}$ & $20 \mathrm{~m}$ & $70 \mathrm{~m}$ \\
& & & \\
\hline
\end{tabular}

The low Gley soil terraces in the mentioned left margin were highlighted in a comparative analysis of the whole alluvial plain, noting the absence or rarity of similar low terraces on the opposite bank. In the right margin, the Jacaré-Guaçu River frequently cuts through the intermediate terraces or slopes directly, suggesting that similar low terraces on the right bank were eventually obliterated by dynamics similar to the lateral migration of the canal's course (Cheliz 2016).

Comparative observations in the vicinity of the left bank of the Jacaré-Guaçu indicate a relatively irregular scenario involving the low terraces with Gley soils (Figure 6). Low terraces with similar gleization soil contents are not observed at the same frequency to the east of the interventions already documented at the BES II site. Therefore, it is a semi-detailed feature, and its preservation can be regarded as significant in surroundings where geomorphogenetic dynamics have already eroded similar geomorphic units. This justifies further analysis with greater attention, as such data would provide evidence of associations between the archaeological and chrono-morphological vestiges that may not have been preserved in the proximal context (Figures 5 and 6). 



Figure 6. Composition with detailed subdivisions of the surroundings of BES II, and general landscape features of the area. Source: Cheliz (2016). 
Rocky outcrops are rare in the bottom set of the valley, where the different levels of the lowland terraces of the Jacaré-Guaçu are located. Specifically, during analysis conducted on the detached low terraces, it was observed that, at certain metrical depths, the recorded pedological coverings result in levels of gravel (Figure 7). These basal conglomerate units that are mostly composed of sandstone pebbles could have served as an alternative source of raw materials for the manufacture of lithic artifacts when their surfaces were exposed.

\section{Profile of cut in aluvial terrace of the Jacaré-Guaçu River}

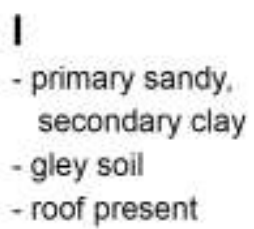

OSL sample
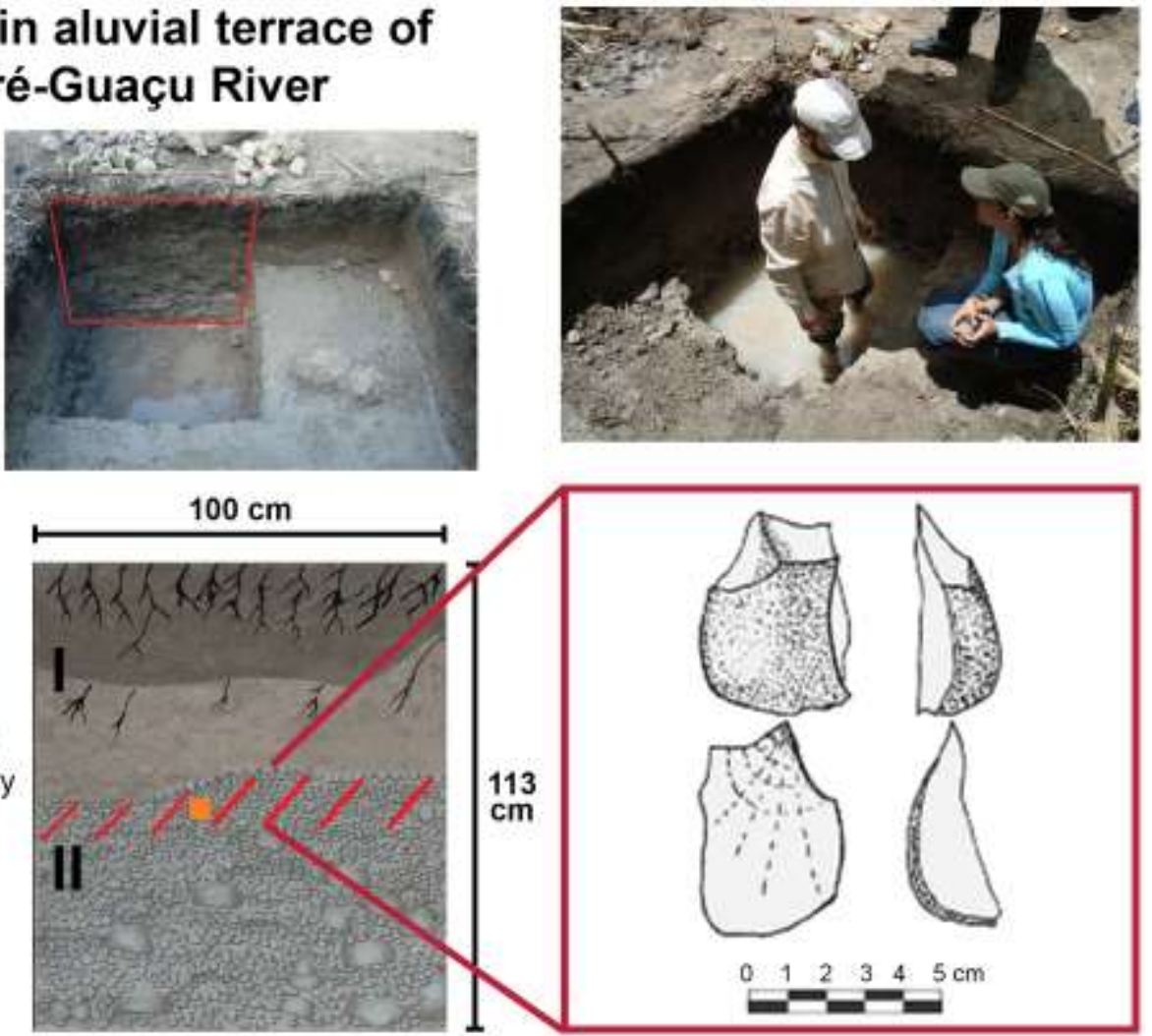

Figure 7. Profile of a lateral cut in the Excavation Unit 01 of 2010 (UE01-2010), and location of OSL sample with a date of 14500+-3000 years BP (FATEC). Source: adapted from Santos (2011); Cheliz (2011; 2016).

The human material remains at site BES II site are distributed in the centre of the aforementioned surface structure of the low terraces, and exhibit a high number of knapped rock materials with a significant diversity of technical functions. Hundreds of flakes and unipolar cores of retouched-edged instruments, over one-hundred hammers, and hundreds of knapping debris are shown (see Figure 8). Most of the raw materials of the artifacts are chert and sandstone with varying degrees of silicification (see Figures 9 and 10). According to the observations of this material, 27 artifacts exhibited some type of thermal alteration, including intense shine and thermal domes, and 17 exhibited patina.

The most representative category of the collection is unipolar flakes, with 627 pieces (543 whole and 84 fragments) - 368 made of chert (58.69\%), 194 of silicified sandstone $(30.94 \%)$, and 54 of quartz (8.61\%), and 10 of sandstone, with $10(1.59 \%)$.

From the identification of the support, it was composed of $35.89 \%$ nodules, $32.06 \%$ pebbles, 26.16\% unidentified material, and 5.90\% blocks. Flakes without cortex are predominant, which appears to agree with the type of industry under analysis. Such flakes would have large cores, and the raw material, i.e., large river pebbles, is mainly used in largevolume supports. The large core allows the removal of significant amounts of flakes without cortex before exhaustion. This is likely the factor responsible for the predominance of such flakes. 


\section{Technological Categories}

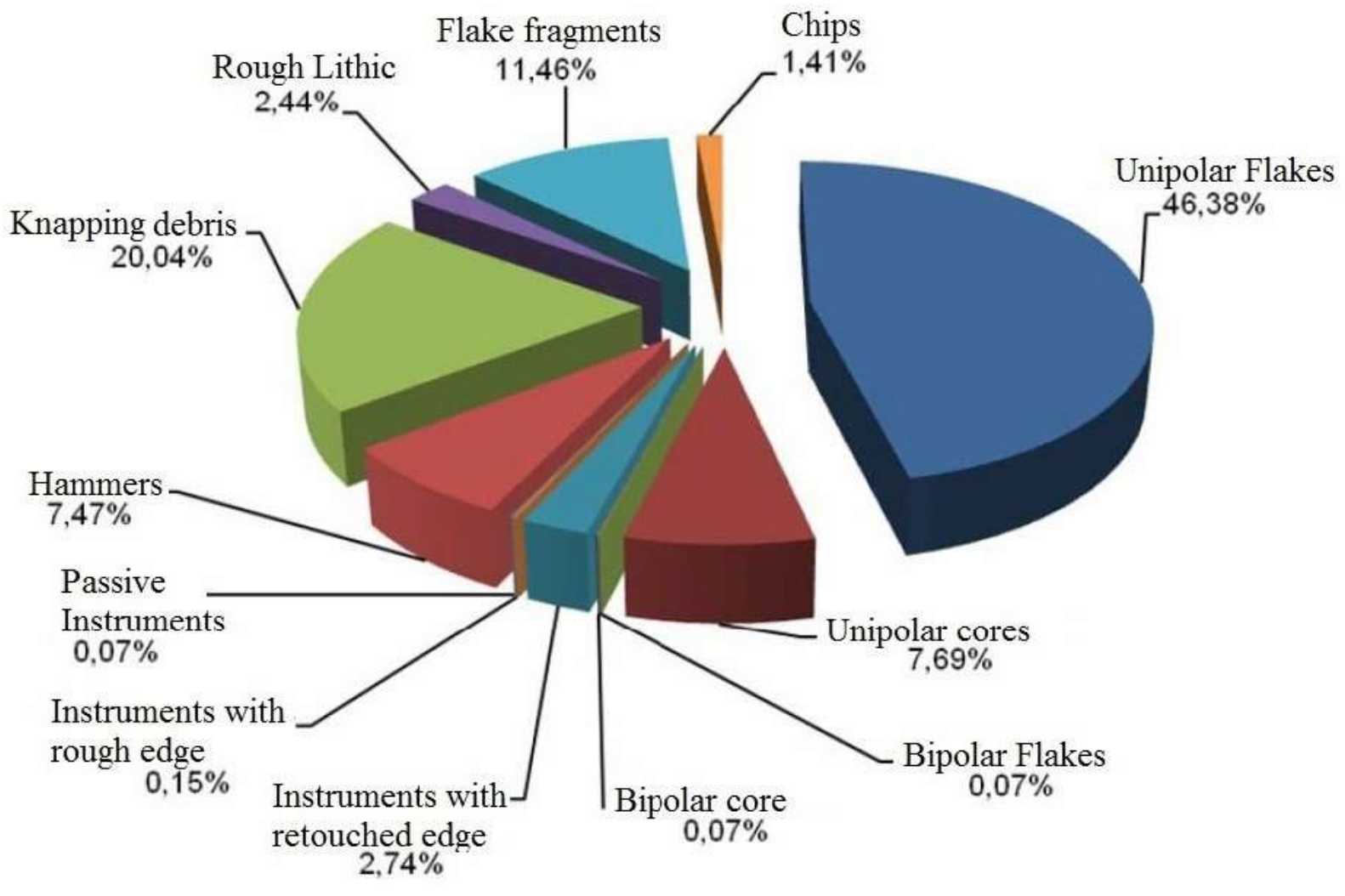

\section{Types of Raw-Material}



Figure 8. Technological categories and types of raw materials from the collection of site BES II. Source: adapted from Santos (2011) and Zanettini Arqueologia (2003). 



Figure 9. Chert artifacts from site BE II. Fonte: adapted from Santos (2011). 



Figure 10. Silicified sandstone artifacts from site BE II. Source: adapted from Santos (2011). 
It should also be noted that the cores are up to $150 \mathrm{~mm}$ in length, $150 \mathrm{~mm}$ in width, and $85 \mathrm{~mm}$ in thickness. Additionally, it is noteworthy that, in this site, a single bipolar flake was still found in the context of a single bipolar core.

Platforms were classified, and smooth platforms were predominant, constituting $46.17 \%$ of the total collection, while the measured angles of the active edges exhibit certain variation. There is a higher frequency of angles between $50^{\circ}$ and $70^{\circ}$ angles, however, angles of $20^{\circ}$, which was the smallest value, and $85^{\circ}$, which was the highest value, were also recorded.

The following general technical sequence for the elaboration of the operative chain in the production of the instruments was suggested: selection of support, detachment of flakes, retouching, and later abandonment of the material. There is also a small number of variants to the chain, including knapping accidents, fragmentation, artifact formatting, recycling, and relatively recent branding (Santos 2011).

Of the 40 collected instruments, 35 are unifacially retouched, whole, or fragmented, and mainly produced with large flakes (conventionalised between 100 and $150 \mathrm{~mm}$ ). We found two perforators, one in chert, shaped into a spearhead but without major touches and with a peduncle. The other is similar in shape to a burin, and is composed of silicified sandstone. There are also two crude-edged instruments, and a passive instrument, i.e., an anvil, with noticeable marks that indicate heavy use. The most-used raw material in the production of these instruments was silicified sandstone, followed by chert. The average length, width, and thickness of the instruments are 135, 75, and $40 \mathrm{~mm}$, respectively. This framework could suggest that site BES II was a settlement with diverse activities, as indicated by the variation in active edges, demonstrating distinct functions. However, the predominance of plain butt platforms indicates the lack of preparation of the impact platform. That is, it is an industry where, perhaps owing to the abundance of raw material, it did not become necessary to exhaustively exploit these pebbles that provided support. The large amount of recorded archaeological material, both vertically and horizontally, indicates intense use of the chipping in this area.

The abundance of the rocky clasts of basal gravels may have contributed to a lithic industry based on obtaining large flakes (between 100 and $150 \mathrm{~mm}$ in length) that were used to retouch most of the instruments. These gravels would have served as an alternative raw material source to the in-situ rocky outcrops of the transitional levels that surround the alluvial plains of the Jacaré-Guaçu River present in the lowlands.

\section{Vertical analysis of the site and data obtained in the context of the surface coverings of the low terraces of the Jacaré-Guaçu River}

A characteristic to be considered regarding the organisation and layout of site BES II, in addition to its horizontal extension and plant locations among the relief compartments of the area, is the site's variations in depth.

The $2 \times 2$ m excavation unit that was opened during the 2010 (UE1-2010) field period (Santos 2011) is a starting point for the presentation and analysis of data when associating the archaeological material with the registered surface cover - see Figure 8. At the basal level, which is covered by gravels, attributes such as high granulometry $(5-20 \mathrm{~cm})$ and a good degree of rounding are noted, with textured patterns combining to indicate the presence of rock fragments transported by fluvial process. This level is highly similar to the other deposits that have already been documented, which are associated with ephemeral torrential channels typically linked to the resumption of the tropical conditions observed in the transition between the Pleistocene and Holocene periods. The similarity to the ephemeral torrential channels can be cited as described by Almeida (1964) and Ab'Saber (1998), among others. 
Such geological record deposit sets resemble those of the current channels in semi-arid areas (Goudie 2013), such as regions of north-western Argentina. The arrival of punctual precipitation with greater intensity and a larger water volume in landscapes predominated by sparse vegetation can generate water flows with high remobilisation capacities. The sparse characteristics of the vegetation indicate that the coverage is insufficient for dispersing a significant part of the kinetic energy of the rainwater. This aids in increasing the transport potential of the water in these ephemeral torrential channels (Ab'Saber 1998), leading to the formation of deposits with significantly higher granulometry than those in the perennial fluvial rivers of tropical climates (Cheliz 2011; 2012; 2015).

Currently, the water flow in the Jacaré-Guaçu River, near site BES II, cannot transport granulometric clasts similar to those that constitute the basal gravel of the excavation unit. The transport ability observed today is limited to the mobilisation of rocky fragmentes that range from a few centimetres to the approximate size of a human fist. The average granulometry of the basal clasts linked to the BES II site is approximately $20 \mathrm{~cm}$.

The sandy-clay intervals that cover the basal rocky clasts can be partially interpreted as deposits of ancient floodplains and others deposits of alluvial plains. These intervals involve the rise of the local base level and the transition from hydrological conditions to perennial rivers, but are still distinct from and much wider than the current, as indicated by abandoned meander-type I in Figures 5 and 6, which is adjacent to the top of the pedosequences (Cheliz 2013 ; 2016). The surface coverings would have later been exposed to the pedogenetic processes involving the visible gleying exhibited by the local soils, which is linked to the establishment of the floodplain connected to the paleochannel of the type-I abandoned meander mentioned above. In a subsequent phase, the terracing of the whole plain and continuation of gleying by the surface segments larger than one-hundred metres indicate the abandonment of the old floodplain and deepening of the canal bed. The ferricretes found on UE1-2010 were consistent with this proposal, indicating at least two major changes in the depths of the local subsurface water nivel. An intense south-north migration (at least of 600 meters) of the Jacaré-Guaçu axis would occur, advancing the hydrological conditions closer to those currently experienced, as the attributes of the type-II abandoned meanders in the floodplains are closer to those currently exhibited by the channel (Figure 5).

Studies were conducted by Cheliz (2016) and Cheliz \& Ladeira (2017) to deepen our knowledge of the three-dimensional characteristics of the local surface coverings initially described by Santos (2011) and Cheliz (2011). Approximately 25 auger holes were created with an average depth of five metres along the area where the test wells and excavation units indicated the presence of archaeological material (Figure 11). The interpretation of the collected data allowed superficial coverings similar to those previously raised and aspects of their lateral variation to be identified. As described in more detail by Cheliz (2016) and Cheliz \& Ladeira (2017), sandy-clay soil mixed with intense gleying is predominant in the horizons, to the extent that all points covered by the auger holes in the low terraces are also considered to be composed of Gley soils (Figure 11). These sets are highly similar to those described in Excavation Unit 1-2010. The three-dimensional characteristics of the subsurface indicate the presence of two types of gravel, one of which is a type II gravel that can reduce the continuity of the holes, suggesting its association with the basal gravel previously detected in UE1-2010. 


\section{Pedosequences - Jacaré-Guaçu low terraces}
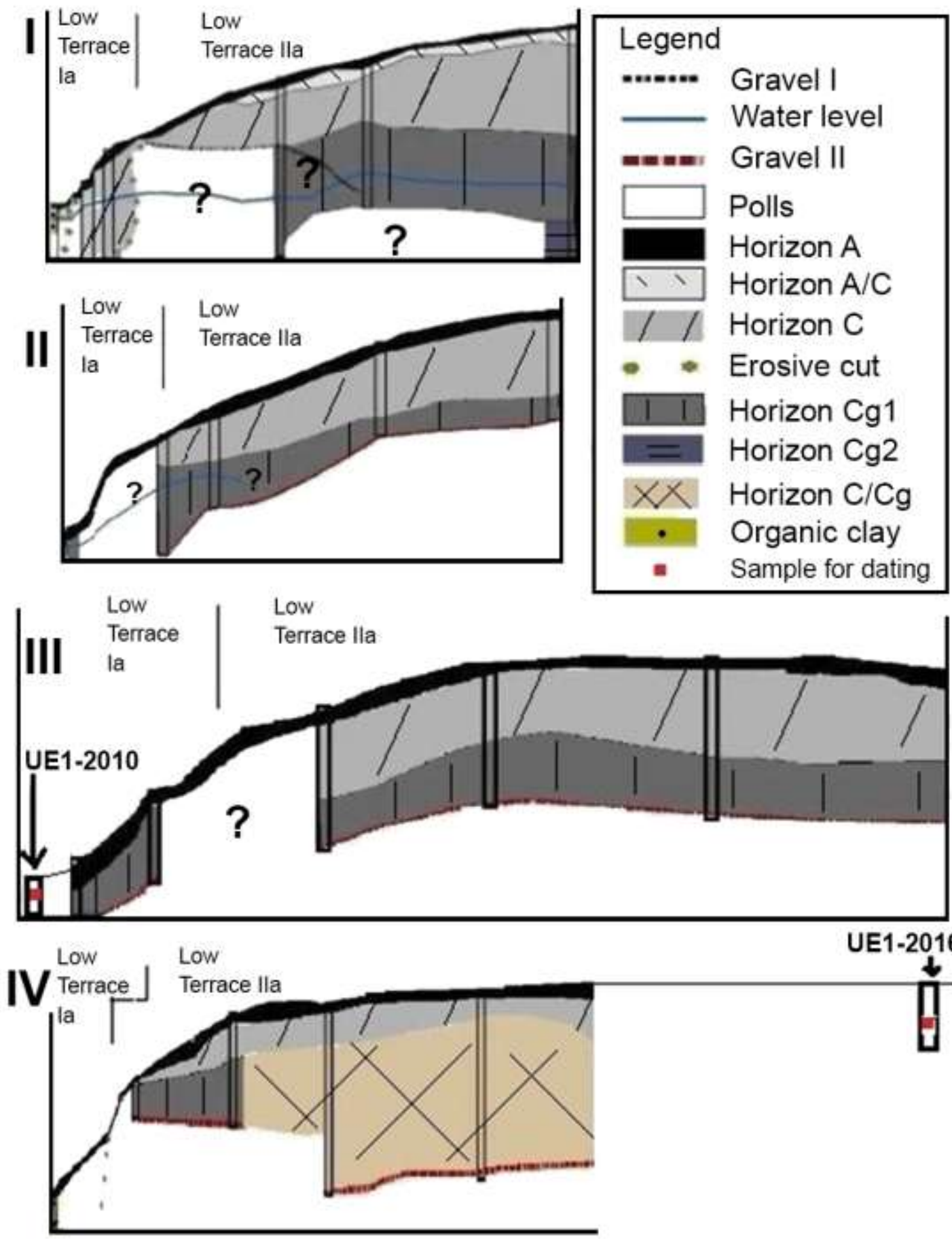

UE1-2016
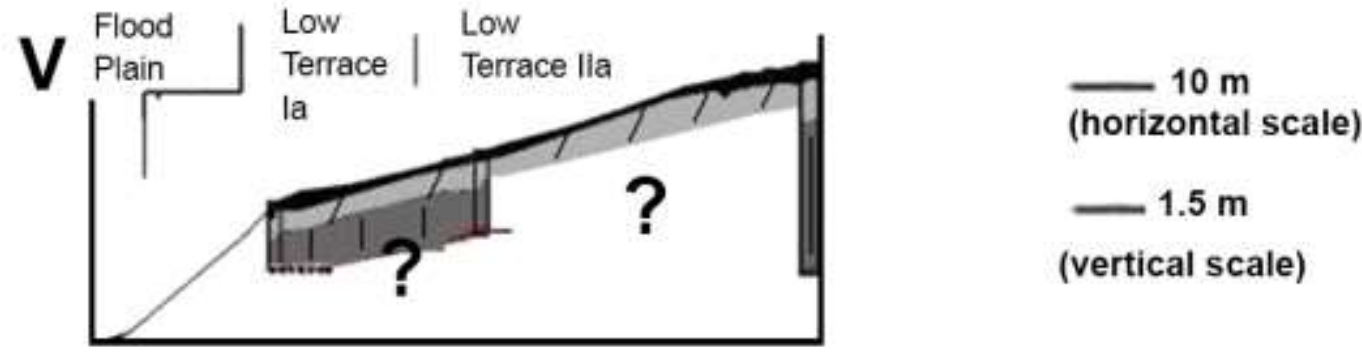

Figure 11. Context of the sites selected for detailing the surface coverage of BES II. Source: adapted from Cheliz (2016). 
Cheliz (2016) and Cheliz \& Ladeira (2017) suggested two chronological and paleoenvironmental successions as possible points for integrating the association of new collected data with those collected in UE1-2010. Both sets incorporate the suggestions proposed in the original interpretations by Cheliz and Oliveira (2011) and Cheliz (2011; 2012; 2015), which are coherent with the assignment of the archaeological from site BES II to the PleistoceneHolocene transition. The estimated chrono-morphological successions can be guided by successive variations in the basal level (rise between the Late Pleistocene and, at least, the Early Holocene, followed by an incision of about 10 meters of the major channel at a later time), and data from the site can be considered in the context of climatic changes from semiarid conditions to higher humidity and modifications of hydrological patterns between the Late Pleistocene and the Holocene, such as the gradation of ephemeral channels (linked to the deposits of basal gravels) to heterogeneous perennial channel regimes (linked to the type I abandoned meander on low terraces a - figure 5 and 6 , and the sandy gley deposits that covers the basal gravels - figures 7 and 11).

The succession of the aforementioned chrono-morphological scenario is similar to that understood for the regional fluvial and base level changes dynamics. This similarity is demonstrated in the studies by Celarino (2011) and Souza (2010) based on pedological, palynological, and carbon-14 dating - on the terraces of the Mogi-Guaçu River, which is tens of kilometres to the northeast of the site discussed here. The data mentioned are compatible with those available on the Jacaré-Guaçu terraces, where site BES II is located. This allows for the possibility of a regional control mechanism for the changes in the referenced base levels, as previously suggested by Cheliz $(2011 ; 2012 ; 2015)$.

The sample sent for OSL dating was obtained from the gravel level near $(15 \mathrm{~cm})$ the stratum that marks the boundary between the basal clast deposit, which is associated with the ephemeral channels formed under transitional conditions from semi-aridity to those of greater humidity, and the sandy-clay Gley soil, which is associated with the floodplains of the perennial channel under high humidity and precipitation. Approximately $70 \%$ of the archaeological material collected in the excavation unit is concentrated in this stratum (Table 3).

At this point, it is appropriate to register the presence of a second dating period for the controlled collection obtained from an excavation unit near the top of pedosequence 4 in 2016 by Araujo and Santos, calibrated from 8850 to 8835 years BP. and obtained using C-14 (Beta Analytic). The referred date was identified in the gleying soil levels shown in Figure 11 and next to to a type I abandoned meander on low terraces a, at a depth of $120 \mathrm{~cm}$. It is located at an archaeologically level, and there are thermal treatment marks on the collected archaeological material (Figure 12) near the sample of coal sent for dating.

The association of the dates, sedimentary-pedological context, and archaeological material allows us to consider the notion of including site BES II in the group of human registries associated with Paleoindian groups, specifically those near the PleistoceneHolocene transition. The uncertainties and questions surrounding such a framework of sites are typically resolved by the confirmation of the solidity of antiquity obtained in diverse dating procedures. An example of this dynamic is in the Ponta de Flecha Abyss, referring to the middle Ribeira do Iguape. The connection between the arrowheads and teeth from Pleistocene animals stated for this region can be questioned by the possibility of transport and remobilisation, as the primary characteristics may have been modified during deposition.

At the Alice Boer site in Rio Claro (São Paulo), there are still uncertainties in the context of the finding. There are still uncertainties regarding the origin of the carbons used for dating by Guidon determined from human activity at sites with even more advanced dates, such as the Pedra Furada site (Piauí). 


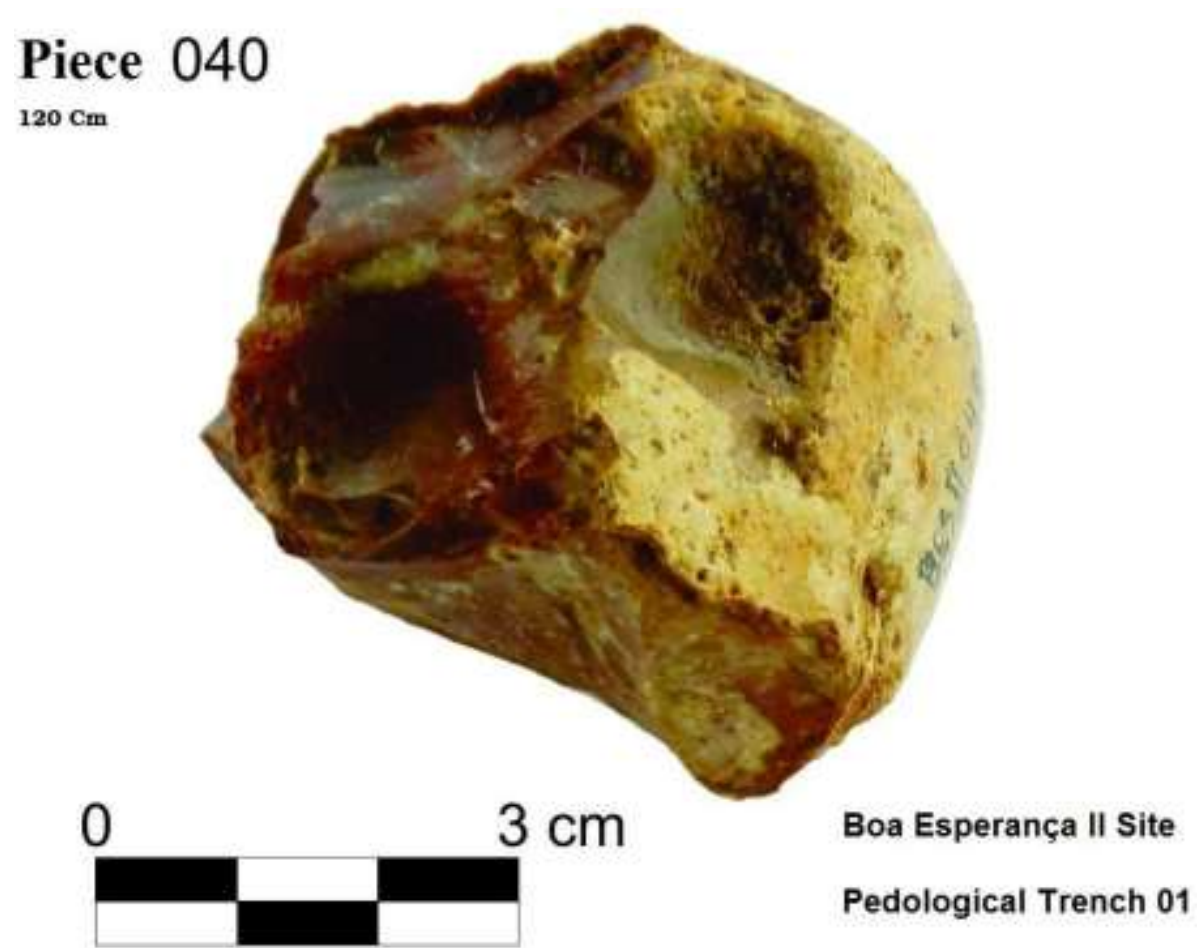

Figure 12. Chert piece with removals and thermic fractures found next to the charcoal sample that was dated to 8.850 to 8.835 years BP by calibrated dating (Beta Analytic). Source: image created by Santos (2018), and charcoal sample sent to the laboratory by Araujo.

However, in the case of UE1-2010 at the BES II site, this situation manifests in a different manner. Several mechanisms contribute to the relatively low probability of vertical movement after the deposition of most of the present artifacts.

One of the first mechanisms to be quoted is the arrangement of the numerous artifacts in a concentrated place, i.e., within the first $20 \mathrm{~cm}$ of the gravel layer (Cheliz 2011; 2015; Santos 2011). As indicated, the samples collected for optically stimulated luminescence dating in UE1-2010 were extracted from an archaeologically intense level associated with hundreds of material traces of human activity (Table 3 and Figure 13).

Table 3. Description of Excavation Unit 01 (2 x2 m) - February 2010 (Source: Santos 2011).

\begin{tabular}{lccccc}
\hline & & \multicolumn{5}{c}{ Artifacts per quadrant (1 × 1 m) } \\
\cline { 3 - 6 } Level & Depth $(\mathbf{c m})$ & NE & SO (SW) & SE & NO (NW) \\
\hline 0 & Surface & 0 & 0 & 0 & 0 \\
01 & $0-10$ & 0 & 0 & 0 & 0 \\
02 & $10-20$ & 0 & 0 & 0 & 0 \\
03 & $20-30$ & 0 & 0 & 0 & 3 \\
04 & $30-40$ & 0 & 0 & 0 & 2 \\
05 & $40-50$ & 1 & 0 & 0 & 202 \\
$\mathbf{0 6}$ (OSL) & $\mathbf{5 0 - 6 0}$ & $\mathbf{2}$ & $\mathbf{0}$ & $\mathbf{5}$ & $\mathbf{2 2 6}$ \\
07 & $60-70$ & 0 & 0 & 0 & 26 \\
08 & $70-80$ & 0 & 0 & 0 & 9 \\
09 & $80-90$ & 0 & 0 & 0 & 0 \\
10 & $90-100$ & 0 & 0 & 0 & 0 \\
11 & $100-110$ & 0 & 0 & 0 & 0 \\
12 & $110-120$ & 0 & 0 & 0 & 0 \\
\hline
\end{tabular}




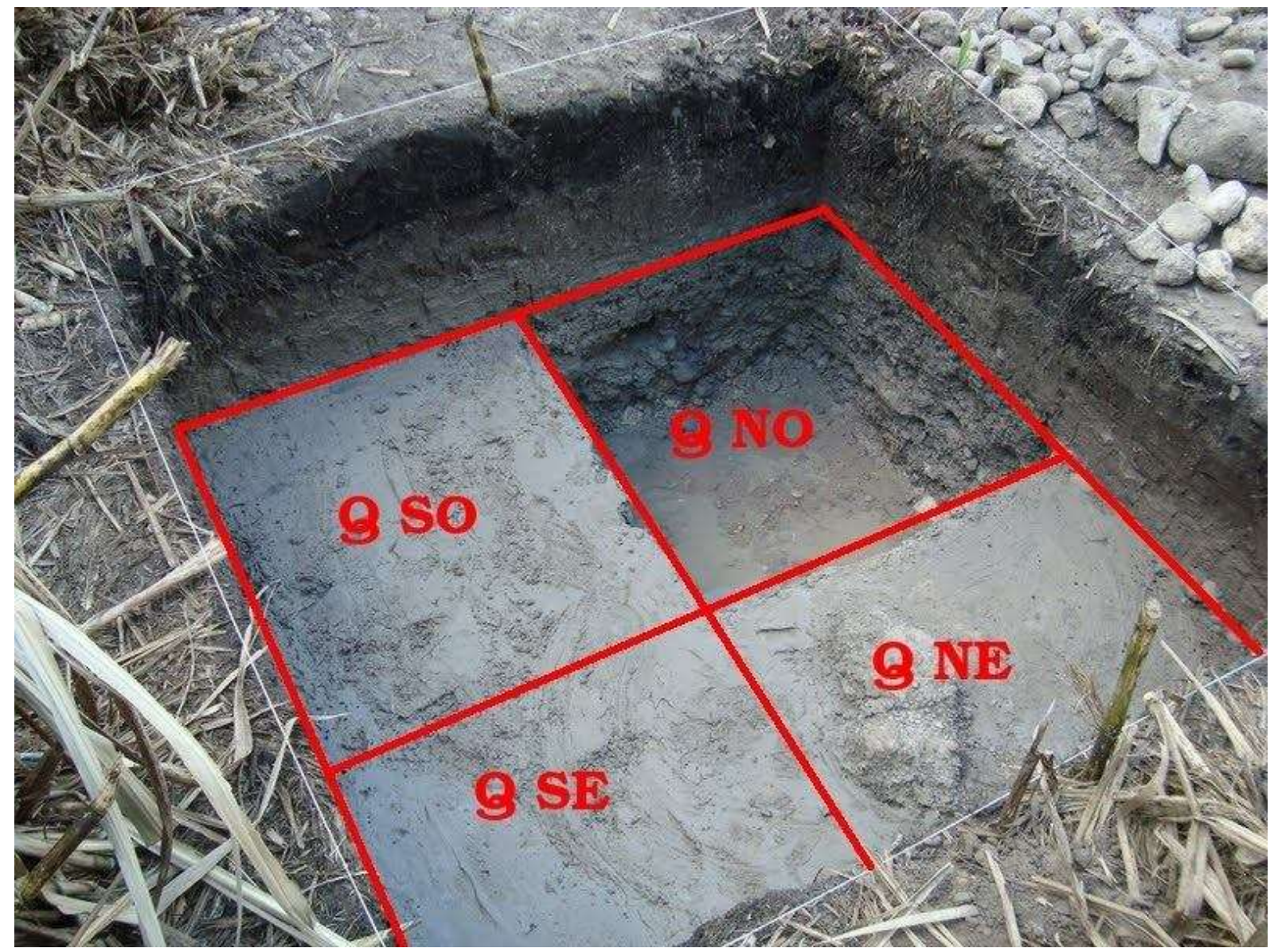

Figure 13. Delimitation of the quadrants in Excavation Unit 01/2010. Source: Santos (2011).

While analysing the vertical distribution of the artifacts from the BES II site (Table 3), we noticed that the archaeological material typically appears along a length of approximately $60 \mathrm{~cm}$, with intense concentration in levels five and six, which mark the upper limit of the basal gravel.

The conditions indicated would hardly be compatible with significant vertical movement processes. Granulometrically, the lithic knapped pieces and rocky fragments in the segment are heterogeneous, and it would be difficult to suggest bioturbation or an active erosive process that could precisely select the lithic materials of archaeological significance and concentrate them in such a narrow vertical band.

The Gley soil inhibits the occurrence of bioturbation, to an extent. The relatively low fertility of the soil mentioned does not favour the installation of some of the most vigorous cerrado ecosystems, diminishing the prospect of biological activity with greater intensity (Cheliz 2011; 2015).

Comparing these data with the settlement patterns of the other lithic sites in the region suggests the presence of larger sites with more pieces, and smaller sites, with restricted activities in their environments. Thus, site BES II exhibits the characteristics of a base or nuclear-dwelling site (Santos 2011). Within this line of reasoning, Santos (2011) considers the presence of smaller contemporary sites in the perimeter of an area established as the territory of these inhabitants, which can be considered "satellite sites" according to the terminology established by De Blasis (1988).

Cheliz $(2011 ; 2015)$ argues that local human groups could have actively benefitted from the attributes derived from the resumption of climate changes in the Pleistocene-Holocene transition, particularly of the exposed gravels formed after the exhaustion of the torrential 
channels responsible for their deposition. Such gravels would be particularly attractive to groups of hunter-gatherers, in the inner cluster of the escarpment in the Paraná Basin.

It is important to remember that, owing to the reduced slopes and the diffusion of deep soils and sedimentary deposits, rocky outcrops are unusual in the valley bottoms in this internalised escarpment area (Cheliz 2011; 2012). Without the abundance of the raw material sources provided by the rocky outcrops for tool making, the importance of the sets of rocky fragments deposited in the trail of torrential channels can be estimated.

Thus, when exposed, the concentration of these gravels is a sufficient reference indicating the periodic returns of human groups to the BES II site. Humans would have used the abundance of pebble-shaped raw materials that made it easier to obtain flakes for creating the instruments necessary for their survival.

Sedimentary processes linked to the rise of the local base level would gradually deposit sandy-clay sediments on the gravel set left by the torrential channels, so they would eventually cover and conceal them from the new human groups arriving in the area. Thus, there was a relative change in the amount of available raw material, and the less-abundant pebbles brought by the new hydrologic system or dispersed sandstone outcrops from the surrounding cliffs (Transitional Nivels) would be used for tool making instead (Cheliz 2012; 2015).

\section{Final considerations}

The BES II site is a part of the internalised segments of the Southern Brazilian Plateau and cuestiforms Escarpment, in the geomorphological context of the lowlands and low terraces of the Jacaré-Guaçu River. As emphasised throughout this text, it is an exceptional interface site-environment in the regional context (Cheliz 2011; 2015; 2016), and is characterised by its rare rocky outcrops and relatively small slopes when compared to the surrounding transitional levels relief partition, which has steeper inclinations and more common rocky outcrops, and contains the majority of sites and regional archaeological sites.

The lithic archaeological pieces of the BES II site and their distribution in the vertical profiles of the local surface structure suggest the historical presence of a hunter-gatherer settlement that would indicate a relatively long period of human occupation (Santos 2011). One possible reason for is the abundance of resources offered by river dynamics, which may be linked to the torrential ephemeral rivers of the Pleistocene-Holocene transition. The surface of the basal gravels of the terraces in the Lowlands would, at the time of the site's constitution, be exposed.

The possible Pleistocene-Holocene transition proximal age of BES II was initially suggested by a single dating involving a sediment sample at the archaeological level, analysed by the optically stimulated luminescence method, which was dated to $14,500+-3,000$ years BP (Santos 2011). The limitation of this being an isolated dating can be clarified by the physicalnatural context, in which the indicated age is accurate in the context of the local (Cheliz 2012; 2016; Cheliz \& Ladeira 2017) and regional (Celarino 2011; Souza 2010) knowledge of the estimated landscapes and chrono-morphological successions. The geomorphological and environmental changes between Late Pleistocene and Holocene on the Jacaré-Guaçu low terraces where is located the BES II site would include rise (about 8 meters) of the base level between the Late Pleistocene and the Early Holocene, followed by an incision (about 10 meters) of the major channel, climatic changes from semiarid conditions to higher humidity, and gradation of ephemeral channels to heterogeneous perennial channel patterns - some of them distinct from the today one perennial Jacaré-Guaçu river (Cheliz; 2011; 2015; 2016). 
The archaeological records of the BES II site suggest that it is included in the physical scenario of the landscape sets traditionally associated with the return of more humid conditions that mark the Pleistocene-Holocene transition in large areas of south-eastern Brazil (Ab'Saber 1998). The basal torrential ephemeral river clasts associated with these sets may have been used as raw material sources for the lithic industry of BES II, and would have been attractive for the periodic return of precursor groups. These sets would have compensated the relative rarity of rocky outcrops in the extensions of the bottom of the valley in which the site is located. It would also enhance the attributes derived from the reduced slopes that benefit human occupation, contrasting with the steeper inclinations of the surrounding relief frames, i.e., the Transitional Nivels.

When considering the insertion of the BES II site in the regional context of interfaces between sites and physical environments (Cheliz 2016), a framework of occupations differing from some models for hunters and gatherers is outlined (Santos 2011). Unlike cases registered in other areas such Alto Taquari (Araujo 1995), which is also located in the countryside of São Paulo, the BES II site did not merge with several small and low-density sites with fewer than twenty pieces each, which constitute $70 \%$ of the sites registered in Alto Taquari with little distance between them, suggesting a small population and high mobility. In contrast, the BES II site was added to other known regional sites, such as those on slopes like Gavião Peixoto II (Cheliz 2015; 2016), or those in lowlands sites like Rincão I (Cheliz 2015; 2016; Galhardo 2010), which are a few tens of kilometres apart and contain hundreds or thousands of already registered pieces. Therefore, it is suggested that the interface discussions of the BES II site can be deepened by considering the modalities of regional occupations, suggesting the possibility of the occurrence of base sites with less mobility (Santos 2011).

From an archaeological viewpoint, although the dating of BES II as being close to the Pleistocene-Holocene transition should still be viewed with caution, it can now be discussed with a more solid basis (Cheliz 2015; Cheliz \& Oliveira 2011; Santos 2011). The dating is not only supported by the two dates obtained by different methods, i.e., C-14 and OSL, at different archaeological levels, with one indicating that the deepest part of the site associated with the basal gravel originated in the Pleistocene or Pleistocene-Holocene transition, and the other indicating an age from the Early Holocene to the more superficial segment, associated with the sandy-clay cover. New studies close to the area in question also support the dating of regional human presence, as they present new data for the Bastos and Caetetuba sites with similar antiquity to that recorded in BES II (Araujo \& Correa 2016; Correia 2017; Trondoso et al. 2016).

The research already underway by the University of São Paulo (USP), Araraquara Archaeologic Museum (MAPA), and the State University of Campinas (UNICAMP - Cheliz and Ladeira) should provide results over the coming years that can deepen these discussions, with diverse and interdisciplinary methods to provide a better understanding of the formation dynamics of the BES II site and its possible insertion in the regional context of the Paleoindian period and Pleistocene-Holocene transition.

\section{Acknowledgements}

We would like to thank Astolfo Araujo (MAE-USP), Francisco Ladeira (IG-UNICAMP), Robson Rodrigues (Fundação Araporã), and Regina Celia de Oliveira (IG-UNICAMP) for supporting the surveys that served as the basis of this article. We thank the respective support teams of USP, UNICAMP, and Fundação Araporã for their assistance in the field surveys. We thank Ricardo Bastos (Café Helena), Helena Bastos and Edson Freitas for the support to the field work. We also thank Zanettini Arqueologia for their support and allowing us to access the information in their technical reports. We thank FAPESP (13/13794-5 process), CAPES, 
and CNPQ for providing material support to this research. Finally, we thank IPHAN for granting authorisation to conduct surveys at the Boa Esperança II archaeological site.

\section{References}

Anonymous 2003, Relatório final do Programa Arqueológico Gasoduto Araraquara / Norte Trecho Boa Esperança do Sul - Araraquara, estado de São Paulo. (Unpublished Report). Zanettini Arqueologia, São Paulo, 95 p. (in Portuguese) ("Final report of the Araraquara-Norte Gas Pipeline Archaeological Program - Boa Esperança do Sul Araraquara, state of São Paulo")

Ab 'Saber, A.N. 1949, Regiões de circudesnudação periférica pós-Cretácea. Boletim Paulista de Geografia, 1: 3-21. (in Portuguese) ("Post-Cretaceous peripheral circudenudation regions")

Ab`Saber, A.N. 1969, Um conceito de geomorfologia a serviço das pesquisas sobre o Quaternário. Geomorfologia, 18: 1-23. (in Portuguese) ("A concept of geomorphology in the service of Quaternary research")

Ab `Saber, A.N. 1998, Participação das depressões periféricas e superfícies aplainadas na compartimentação do Planalto Brasileiro. Revista do Instituto Geológico, 19: 51-69. (in Portuguese) ("Participation of peripheral depressions and flattened surfaces in the Brazilian Plateau compartmentalization")

Almeida, F.F.M. 1964, Fundamentos geológicos do relevo paulista. Boletim do Instituto Geográfico e Geológico, 41: 69-263. (in Portuguese) ("Geological foundations of São Paulo relief")

Araujo, A.G.d.M. 1995, Levantamento arqueológico da área Alto Taquari, estado de São Paulo, com ênfase na abordagem dos sítios líticos. Master's thesis at the Faculdade de Filosofia e Ciências Humanas, Universidade de São Paulo, São Paulo, 130 p. (in Portuguese) ("Archaeological survey of the Alto Taquari area, São Paulo state, with emphasis on the approach of the lithic sites")

Araujo, A.G.d.M. 2004, A variabilidade cultural no período Paleoíndio (11.000-8.000 AP) no Brasil: Algumas hipóteses. Revista do CEPA, Santa Cruz do Sul, 28: 111-130. (in Portuguese) ("Cultural variability in the Paleoindian period (11,000-8,000 BCE) in Brazil: Some hypotheses")

Araujo, A.G.d.M. \& Correa, L. 2016, First notice of a Paleoindian site in central São Paulo state, Brazil: Bastos Site, Dourado county. Paleoindian Archaeology, 1: 4-14. URL: https://journals.kvasirpublishing.com/pa/article/view/17

Araujo, A.G.d.M. \& Neves, W. 2012, A ocupação Paleoindia do sudeste brasileiro: Lagoa Santa e Além. In: Tempos Ancestrais (Morales, W.F. \& Moi, F.P., Eds.), Editora Annablume - NEPAB, São Paulo: p. 47-71. (in Portuguese) ("The Paleoindian occupation of southeastern Brazil: Lagoa Santa and beyond")

Araujo, A.G.d.M., Paisani, J.C., Schrage, T.J., Feathers, J.K., Hartmann, G.A. \& Ricci, O. 2017, The "Lagoa do Camargo 1" Paleoindian site: Some implications for tropical geomorphology, pedology, and paleoenvironments in southeastern Brazil. Geoarchaeology, 32: 662-677. doi:10.1002/gea.21628 
Araujo, A.G.d.M., Sousa, J.C.M., Correia, L.C. \& Okumura, M.M. 2017, O sítio arqueológico Alice Boer, Rio Claro - SP: Processos de formação e novos dados cronológicos e arqueológicos. In: Anais do XVI Congresso Assoaciação Brasileira do Quaternário, Associação Brasileira de Estudos do Quaternário (ABEQUA), Peruíbe: p. 1 p. (in Portuguese) ("The archaeological site Alice Boer, Rio Claro, SP: Formation processes and new chronological and archaeological data")

URL: http://www.abequa.org.br/trabalhos/119_resumo.PDF

Bate, L.F. 1990, Culturas y modos de vida de los cazadores recolectores en el poblamiento de America del Sur. Revista de Arqueología Americana, 2: 89-153. (in Spanish) ("Cultures and ways of life of the hunter gatherers in the settlement of South America")

Beltrão, M.C. 1974, Datações arqueológicas mais antigas do Brasil. Anais da Academia Brasileira de Ciências, 46: 211-251. (in Portuguese) ("The oldest archaeological datings in Brazil")

Bradley, B. \& Stanford, D. 2004, The North Atlantic ice-edge corridor: A possible Palaeolithic route to the New World. World Archaeology, 36: 459-478. doi:10.1080/0043824042000303656

Brèzillon, M. 1977, La dénomination des objets de pierre taillée. Suplément à Gallia Préhistorie Vol. 4. Centre national de la recherche scientifique (CNRS), Paris, 423 p. (in French) ("The naming of knapped stone objects")

Brown jr, K.S. \& Ab 'Saber, A.N. 1979, Ice-age forest refuges and evolution in the Neotropics: Correlation of palaeoclimatological, geomorphological and pedological data with modern biological endemis. Paleoclimas, 5: 1-30.

Bueno, L.D.M.R. 2016, Variabilidade tecnológica nos sítios líticos da região do Lajeado, Médio Rio Tocantins. Revista do Museu de Arqueologia e Etnologia. Suplemento, 4: 215 p. (in Portuguese) ("Technological variability in the lithic sites of Lajeado region, Middle Tocantins River") doi:10.11606/issn.2594-5939.revmaesupl.2007.113483

Bueno, L.D.M.R., Dias, A.S. \& Steele, J. 2013, The Late Pleistocene/Early Holocene archaeological record in Brazil: A geo-referenced database. Quaternary International, 301: 74-93. doi:10.1016/j.quaint.2013.03.042

Campos de Mello, P.J. 2007, Teoria e método: Possibilidades de abordagem em indústrias expedientes. In: Das Pedras aos Homens: Tecnologia Lítica na Arqueologia Brasileira (Bueno, L.D.M.R. \& Isnardis, A., Eds.), Argvmentvm, Belo Horizonte: p. 420. (in Portuguese) ("Theory and method: Possibilities of approach in expedient industries")

Celarino, A. 2011, Análise cronológica e pedológica de uma topossequência na Estação Ecológica de Jataí, Luis Antonio - SP: Relação entre processos pedogenéticos na vertente e na planície aluvial do rio Mogi Guaçu. Mater's thesis at the Instituto de Geociências, Universidade Estadual de Campinas, Campinas, 123 p. (in Portuguese) ("Chronological and pedological analysis of a toposequence at the Jataí Ecological Station, Luis Antonio - SP: Relationship between pedogenetic processes on the Mogi Guaçu River slope and alluvial plain") 
Cheliz, P.M. 2011, Implicações quaternárias da geomorfogênese de um segmento das cuestas basálticas: Aspectos geomorfológicos e arqueológicos. In: Anais do XIII Congresso da Associação Brasileira de Estudos do Quaternário ABEQUA. III Encontro do Quaternário Sulamericano. XIII ABEQUA Congress - The South American Quaternary: Challenges and Perspectives, Associação Brasileira de Estudos do Quaternário (ABEQUA), Buzius: p. 4. (in Portuguese) ("Quaternary implications of geomorphogenesis of a basaltic cuesta segment: Geomorphological and archaeological aspects")

Cheliz, P.M. 2012, Dinâmica fluvial Quaternária e influência estrutural no modelado do relevo: Ponderações a partir das cuestas concêntricas. In: Anais do I Congresso de Geologia dos Países de Língua Portuguesa / 46 Congresso Brasileiro de Geologia, Sociedade Brasileira de Geologia, Santos: p. 1 p. (in Portuguese) ("Quaternary river dynamics and structural influence in relief modeling: Weighting from concentric cuestas")

Cheliz, P.M. 2013, Quadros ambientais e ocupação humana pretérita: bases físicas da pesquisa arqueológica em Araraquara. In: Compilação de Atividades de 2013 da Fundação Araporã. Araraquara (Rodrigues, R.A., Ed.), Museu de Arqueologia e Paleontologia de Araraquara, Araraquara: p. 20-53. (in Portuguese) ("Environmental frameworks and past human occupation: Physical bases of archaeological research in Araraquara") URL: https://www.researchgate.net/publication/337324327

Cheliz, P.M. 2015, Interface entre quadros de relevo cuestiformes e registros arqueológicos líticos: Cercanias de Araraquara, nordeste paulista, São Paulo, Brasil. Meridiano Revista de Geografía, 4: 135-160. (in Portuguese) ("Interface between cuestiform relief frames and lithic archaeological records: Araraquara outskirts, São Paulo northeast, São Paulo, Brazil")

Cheliz, P.M. 2016, Aspectos geomorfológicos da antiga Araraquara, com ênfase em subsídios para interface entre quadros de relevo e sítios arqueológicos líticos. Undergraduate thesis at the Departamento de Geologia, Instituto de Geociências, Universidade Estadual de Campinas, Campinas, 115 p. (in Portuguese) ("Geomorphological aspects of the ancient Araraquara, with emphasis on subsidies to interface between framework relief and lithic archaeological sites")

Cheliz, P.M. \& Ladeira, F.S.B. 2017, Contextualização de aspectos geomorfológicos e da cobertura superficial do Sítio Boa Esperança II (interior paulista), como subsídio para a discussão de sua antiguidade. In: Os Desafios da Geografia Física na Fronteira do Conhecimento (Perez Filho, A.A.R.r., Ed.), Universidade Estadual de Campinas (UNICAMP), Campinas: p. 6274-6288. (in Portuguese) ("Contextualization of geomorphological aspects and surface coverage of the Boa Esperança II site (interior of São Paulo), as a subsidy for the discussion of its antiquity") doi:10.20396/sbgfa.v1i2017.2530

Cheliz, P.M. \& Oliveira, R.C. 2011, A antiguidade da presença humana em São Paulo: Uma discussão interdisciplinar. In: Programa Institucional de Iniciação Científica da UNICAMP DA Universidade Estadual de Campinas (Edição 2011), Universidade Estadual de Campinas (UNICAMP), Campinas: p. 1 p. (in Portuguese) ("The antiquity of the human presence in São Paulo: An interdisciplinary discussion") 
Correa, L. 2017, As industrias líticas do Holoceno no interior paulista: Estudo de caso dos sítios Abrigo do Alvo e Bastos. Master's thesis at the Museu Arqueologia e Etnologia, Universidade de São Paulo, São Paulo, 168 p. (in Portuguese) ("Holocene lithic industries in São Paulo state: Case study of the Abrigo do Alvo and Bastos sites") doi:10.11606/D.71.2017.tde-18102017-171844

de Blasis, P.A.D. 1989, A ocupação pré-colonial do Vale do Ribeira do Iguape, SP: Os sítios líticos do médio curso. Master's thesis at the Faculdade de Filosofia, Letras e Ciências Humanas, Universidade de São Paulo, São Paulo, 215 p. (in Portuguese) ("The precolonial occupation of the Ribeira do Iguape Valley, SP: The lithic sites of the middle course")

Figueiroa, S.F.M. 1987, Modernos Bandeirantes: A Comissão Geográfica e Geológica de São Paulo e a exploração científica do território paulista (1886-1931). Ph.D. thesis at the Faculdade de Filosofia, Letras e Ciências Humanas, Universidade de São Paulo, São Paulo, 164 p. (in Pedro) ("Modern Bandeirantes: The Geographic and Geological Commission of São Paulo and the scientific exploration of São Paulo (1886-1931)")

Goudie, A. 2013, Arid and semi-arid geomorphology. Cambridge University Press, New York, 470 p. doi:10.1017/cbo9780511794261

James Dixon, E. 2001, Human colonization of the Americas: Timing, technology and process. Quaternary Science Reviews, 20: 277-299. doi:10.1016/s0277-3791(00)00116-5

Laming-Emperaire, A. 1967, Guia para o estudo das industrias liticas da America do Sul. Arqueologia, 12: 155 p. (in Portuguese) ("Guide to the styudy of lithic industries of South America") URL: https://journals.kvasirpublishing.com/arq/article/view/68

Lee, R.B. \& Devore, I. 1968, Man the hunter (1st ed.). Aldine, Chicago, 415 p.

Mano, M. 2006, Os campos de Araraquara: Um estudo de história indígena no interior paulista. Ph.D. thesis at the Instituto de Filosofia e Ciências Humanas, Universidade Estadual de Campinas, Campinas, 357 p. (in Portuguese) ("The fields of Araraquara: A study of indigenous history in the interior of São Paulo")

Mendes, D.T. 2014, Tecnologia lítica no Médio Paranapanema : Um estudo de caso das ocupações da transação Holoceno Inicial-Médio do sítio Brito (Sarutaiá/SP). Master's thesis at the Museu de Arqueologia e Etnologia, Universidade de São Paulo, São Paulo, 155 p. (in Portuguese) ("Lithic technology in the middle Paranapanema: A case study of the Early/Middle Holocene ocuppations of the Brito site (Sarutaiá, SP)") doi:10.11606/D.71.2014.tde-09122014-161815

Morais, J.L. 1983, Estudo do sítio Camargo 2 - Piraju/SP: Ensaio tecnotipológico de sua indústria lítica. Revista do Museu Paulista, Nova Série, 33: 41-128. (in Portuguese) ("Camargo 2 Site Study - Piraju, São Paulo: Technotypical essay of its lithic industry")

Santos, F.G. 2009, Os habitantes mais antigos do centro-oeste paulista. Mimesis, 30: 25-59. (in Portuguese) ("The oldest inhabitants of the São Paulo midwest ")

Santos, F.G. 2011, Sítios líticos do interior paulista: Um enfoque regional. Master's thesis at the Museu de Arqueologia e Etnologia, Universidade de São Paulo, São Paulo, 182 p. (in Portuguese) ("Lithic sites of the interior of São Paulo: A regional approach")

Santos, F.G. 2013, Abordagem teórica sobre o estudo de sítios líticos no interior do estado de São Paulo, Brasil. Techné, 1: 39-49. (in Portuguese) ("Theoretical approach to the study of lithic sites in the interior of São Paulo state, Brazil") 
Souza, M.M. 2010, Palinologia em sedimentos quaternários, localizados na Estação do Instituto Florestal de Jataí, SP. Master's thesis at the Instituto de Geociências, Universidade Estadual de Campinas, Campinas, 79 p. (in Portuguese) ("Palinology in Quaternary sediments, located at Jataí Forest Institute Station, SP")

Tixier, J., Inizan, M.L., Roche, H. \& Dauvois, M. 1980, Préhistoire de la pierre taillée. Vol. 1: Terminologie et technologie. Cercle de Recherches et d'Études Préhistoriques (Meudon, Hauts-de-Seine) (CREP), Valbonne, 199 p. ("Prehistory of knapped stone. Vol. 1: Terminology and technology")

Troncoso, L.d.P.S., Côrrea, A.A. \& Zanettini, P.E. 2016, Paleoíndios em São Paulo: Nota a respeito do sítio Caetetuba, município de São Manuel, SP. Paleoindian Archaeology, 1: 50-71. (in Portuguese) ("Paleoindians in São Paulo: Note about the Caetetuba site, municipality of São Manuel, SP")

URL: https://journals.kvasirpublishing.com/pa/article/view/14/

Vialou, A.V. 1983, Brito: O mais antigo sítio arqueológico do Paranapanema, estado de São Paulo. Separata da Revista do Museu Paulista, Nova Série, 39: 9-21. (in Portuguese) ("Brito: The oldest archaeological site of the Paranapanema, state of Sao Paulo") 